\title{
Pelatihan Teknologi PHT pada Usaha Tani Cabai Merah di Desa Dukuh Dempok, Kabupaten Jember
}

\section{(IPM Technology Training for Red Chili Pepper Farming in Dukuh Dempok Village, Jember District)}

\author{
Eliyatiningsih ${ }^{1}$, Iqbal Erdiansyah ${ }^{1}$, Sekar Utami Putri' ${ }^{1}$ Dany Hisbullah Al Huda ${ }^{2}$, \\ Ramadhana Putra Pratama ${ }^{2}$ \\ ${ }^{1}$ Jurusan Produksi Pertanian, Politeknik Negeri Jember, Jl. Mastrip, Lingkungan Panji, Tegalgede, Sumbersari, \\ Jember 68124. \\ 2 Mahasiswa Jurusan Produksi Pertanian, Politeknik Negeri, Jl. Mastrip, Lingkungan Panji, Tegalgede, Sumbersari, \\ Jember 68124 \\ *Penulis korespondensi: eliyatiningsih@polije.ac.id \\ Diterima Desember 2019/Disetujui Februari 2021
}

\begin{abstract}
ABSTRAK
Desa Dukuh Dempok merupakan salah satu sentra produksi cabai merah di Kabupaten Jember. Permasalahan yang dihadapi petani adalah adanya serangan organisme pengganggu tumbuhan (OPT). OPT yang menyerang di antaranya adalah kutu kebul (Bemisia tabaci), thrips, antraknosa, dan layu fusarium. Tujuan kegiatan pengabdian kepada masayarakat ini adalah memberikan edukasi dan pelatihan terkait pengendalian hama secara terpadu (PHT) pada budi daya cabai merah. Pelatihan yang dilakukan meliputi perbanyakan agensia hayati Beauveria bassiana dan pupuk hayati Trichoderma, serta penanaman bunga refugia di sekitar pertanaman cabai merah. Pelatihan dilakukan dengan metode demonstrasi plot. Dari hasil kegiatan penyuluhan diperoleh data peningkatan pengetahuan petani terkait dengan pengendalian PHT. Rata-rata nilai pre-test sebelum kegiatan adalah 41,5 dan rata-rata nilai post-test petani setelah kegiatan adalah 87 . Setelah kegiatan pelatihan petani mitra juga mampu melakukan perbanyakan agensia hayati dan membuat pupuk hayati serta mengaplikasikannya pada lahan budi daya cabai merah. Dari hasil evaluasi diketahui bahwa aplikasi B. bassiana, penanaman bunga refugia, dan aplikasi Trichoderma sp. atau metode Beart dapat menekan penggunaan pestisida hingga 50\%. Dari kegiatan tersebut petani mendapatkan tambahan pengetahuan dan teknologi baru yang berwawasan lingkungan terkait budi daya cabai merah yang bermanfaat untuk meningkatkan produksi, mengurangi penggunaan pestisida, menekan biaya produksi, dan memperoleh keuntungan yang maksimal.
\end{abstract}

Kata kunci: Beauveria bassiana, metode beart, refugia, trichoderma

\begin{abstract}
Dukuh Dempok Village is one of the centers of red chili pepper production in Jember District. The problem faced by farmers is the presence of pest attacks.The pests that attack include whitefly (Bemisia tabaci), thrips, anthracnose and fusarium wilt. The purpose of this community service program is to provide education and training related to integrated pest control (IPM) in red chili cultivation. The training includes the multiplication of biological agents Beauveria bassiana and biofertilizer Trichoderma, as well as planting of refugia flowers around the red chili plantations. The training was conducted using the plot demonstration method. From the results of extension activities, data on farmers' knowledge improvement related to IPM control were obtained. The average pre-test score before the activity was 41.5 and the average post-test score of farmers after the activity was 87 . After the training, the partner farmers were also able to multiply biological agents and make biological fertilizers and apply them to red chili cultivation. From the evaluation results, it is known that the application of B. bassiana, planting of refugia flowers, and the application of Trichoderma sp or the Beart method can reduce the use of pesticides by up to $50 \%$. From these activities, farmers get new knowledge and technology related to red chili cultivation which is useful for increasing production, reducing pesticide use, reducing production costs, and obtaining maximum profits.
\end{abstract}

Keywords: Beauveria bassiana, beart methods, refugia, trichoderma 


\section{PENDAHULUAN}

Kecamatan Wuluhan merupakan daerah sentra budi daya cabai merah di Kabupaten Jember. Badan Pusat Statistik mencatat luas areal panen cabai merah di Wuluhan pada tahun 2016 mencapai 261 ha dengan produksi mencapai 16.496 kw. Jumlah produksi ini mencapai lebih dari $29 \%$ dari total produksi cabai merah di Kabupaten Jember (Badan Pusat Statistik 2015). Salah satu sentra produksi cabai merah di Kecamatan Wuluhan adalah Desa Dukuh Dempok. Musim tanam cabai di desa Dukuh Dempok adalah pada bulan April-September. Secara umum produksi cabai merah di Desa Dukuh Dempok berfluktuasi. Jumlah produksi yang naik turun ini dapat menyebabkan harga pasar tidak stabil sehingga merugikan petani.

Fluktuasi produksi cabai merah yang terjadi pada kelompok tani di Desa Dukuh Dempok disebabkan oleh beberapa hal antara lain lingkungan yang tidak mendukung seperti kesuburan tanah yang mulai menurun, serangan OPT (Organisme Pengganggu Tanaman) yang tinggi, dan penggunaan pestisida yang berlebihan. Lingkungan yang tidak mendukung akan memengaruhi pertumbuhan, perkembangan tanaman, dan kerentanan tanaman terhadap OPT. Tindakan petani yang biasa dilakukan ketika terdapat serangan OPT tinggi adalah aplikasi pestisida yang terus menerus. Aplikasi pestisida kimia dalam satu kali musim tanam dapat dilakukan kurang lebih 35 kali penyemprotan. Hal ini akan berdampak pada resistensi hama terhadap pestisida meningkat.

Resistensi pestisida mengakibatkan terjadinya ledakan hama. Beberapa OPT yang kerap meresahkan petani cabai merah di Desa Dukuh Dempok adalah Bemisia tabaci, thrips, dan lalat buah, sementara penyakit yang menyerang adalah patek atau antraknosa, layu fusarium, dan layu bakteri. Akibat serangan hama dan penyakit ini maka petani sering mengalami kerugian hingga gagal panen. Hasil penelitian Narendra et al. (2017) menyatakan kelimpahan populasi hama kutu kebul berkorelasi positif terhadap penyakit kuning pada tanaman famili Solanacea seperti tomat dan cabai. Hama Bemisia tabaci juga menjadi vektor Tomato Yellow Leaf Curl Virus (TYLCV) yang menyerang tanaman cabai dan mampu menurunkan hasil panen hingga 2080\% (Sudiono \& Yasin 2006). Selain itu, serangan penyakit antraknosa yang menyebabkan busuk buah pada cabai dapat terjadi baik musim hujan maupun kemarau, dan apabila tidak dilakukan pengendalian secara tepat dapat menyebabkan kerugian hingga 50\% (Duriat 2015)

Upaya untuk menanggulangi permasalahan serangan OPT pada tanaman cabai merah dapat dilakukan dengan penerapan teknologi pengendalian hama terpadu atau PHT, yang merupakan pengendalian hama yang dilakukan dengan menggunakan kekuatan unsur-unsur alami yang mampu mengendalikan hama agar tetap berada pada jumlah di bawah ambang batas yang merugikan (Juanda \& Cahyono 2005). Salah satu prinsip dasar sistem PHT adalah budi daya tanaman sehat dan pemanfataan musuh alami (Untung 2015). Salah satu teknologi PHT yang coba diperkenalkan kepada petani adalah metode Beart, yaitu aplikasi B. bassiana dan Trichoderma sp. serta penggunaan bunga refugia yang bisa dipadukan untuk diaplikasikan pada pertanaman cabai. B. bassiana diketahui dapat menjadi agen hayati hama kutu kebul (Hidayat et al. 2010). Sementara bunga refugia yang ditanam di sekitar areal pertanaman atau di pembatas lahan dapat berfungsi sebagai mikro habitat bagi predator atau musuh alami hama. Penanaman refugia dapat meningkatkan populasi predator dan parasitoid yang telah menurun karena aplikasi pestisida yang berlebihan (Erdiansyah \& Putri 2017). Pemberian pupuk hayati Trichoderma berfungsi sebagai biofungisida yang bersifat antagonistik terhadap jamur lain. Trichoderma mempunyai daya antagonis tinggi dan dapat mengeluarkan racun, sehingga dapat menghambat bahkan mematikan patogen lain (Rahmawati 2016).

Serangan OPT dengan intensitas tinggi mengakibatkan usaha tani cabai merah memiliki resiko usaha yang besar. Besarnya resiko usaha tani dapat diatasi dengan membuat perencanaan usaha tani yang baik dan perencanaan usaha tani akan dapat dilakukan apabila petani melakukan manajemen dalam usahataninya. Salah satu contoh manajemen usaha tani adalah membuat pembukuan usaha tani, namun disayangkan hampir sebagian besar petani dalam menjalankan usahataninya tidak pernah melakukan pencatatan penerimaan dan pengeluaran dalam usahataninya. Mereka hanya mengingat-ingat biaya-biaya real yang dikeluarkan dalam menjalankan usahataninya (Leatema \& Sari 2012). Pembukuan usaha tani tersebut dapat membantu mereka dalam melakukan perencanaan usaha pada musim tanam berikut, mengetahui apakah usaha tani tersebut untung atau rugi dan sebagai bahan evaluasi kegiatan usaha tani dalam satu tahun. 
Pengendalian OPT terpadu selama ini telah berkembang dengan baik di beberapa wilayah. Teknologi ini selain efektif menekan serangan OPT di pertanaman petani, juga ramah lingkungan. Kegiatan pengabdian kepada masyarakat ini bertujuan untuk mengedukasi dan menambah pengetahuan serta keterampilan petani cabai merah di Desa Dukuh Dempok, Kecamatan Wuluhan, Kabupaten Jember dalam melakukan pengendalian OPT terpadu pada budi daya cabai merah yang mereka lakukan. Teknologi pengendalian OPT terpadu selain dapat menekan populasi hama dan penyakit tanaman cabai merah, juga diharapkan dapat menekan biaya produksi usaha tani untuk membeli pestisida kimia, serta menciptakan budi daya pertanian yang sehat.

\section{METODE PELAKSANAAN KEGIATAN}

\section{Waktu dan Tempat}

Kegiatan program kemitraan masyarakat dilaksanakan di Dusun Gawok, Desa Dukuh Dempok, Kecamatan Wuluhan, Kabupaten Jember, pada bulan Mei-September 2019. Mitra kegiatan adalah petani cabai merah yang tergabung dalam Kelompok Tani Aneka Maju yang beranggotakan 25 petani. Pemilihan mitra ini didasarkan atas adanya permasalahan yang mendesak, yaitu terjadinya serangan OPT yang dihadapi petani yang terjadi setiap musim tanam.

\section{Bahan dan Alat}

Bahan yang dibutuhkan dalam pelatihan metode Beart diantaranya beras jagung, isolat Trichoderma $\mathrm{sp}$, isolat $B$. bassiana, benih refugia (bunga kertas dan kenikir), bibit cabai merah, pupuk kandang, pupuk kimia, pestisida kimia (demolis, pegasus, endure), dan hormon tanaman. Alat yang digunakan dalam kegiatan ini adalah dandang, enkas, bunsen, plastik, ring, dan tali.

\section{Metode Pelaksanaan}

Tahapan pelaksanaan kegiatan pelatihan teknologi pengendalian hama terpadu (PHT) pada kegiatan pengabdian ini meliputi:

\section{- Sosialisasi awal}

Kegiatan sosialisasi dimulai dengan diskusi terkait rencana kegiatan pengabdian kepada kelompok tani. Kegiatan sosialisasi diawali dengan pre-test yang bertujuan untuk mengetahui sejauh mana petani paham terkait teknologi pengendalian hama terpadu (PHT) pada budi daya cabai merah. Sosialisasi dilanjutkan dengan kegiatan edukasi atau penjelasan materi tentang beberapa hama dan penyakit yang menyerang tanaman cabai merah, beserta cara pengendaliannya secara bijak. Dalam kegiatan ini juga dijelaskan tentang pengendalian hama yang ramah lingkungan yang dikenal dengan metode pengendalian hama terpadu (PHT).

\section{- Penyuluhan}

Kegiatan penyuluhan yang dilakukan meliputi pelatihan pembuatan pupuk hayati Trichoderma, perbanyakan agensia hayati Beveuria bassiana, dan pengenalan bunga refugia. Teknologi pengendalian OPT terpadu ini disebut metode Beart. Pupuk hayati dan agensia hayati dibuat dari media beras jagung dan isolat berasal dari Laboratorium Perlindungan Tanaman Politeknik Negeri Jember. Penyiapan media diawali dengan mencuci bersih beras jagung dan kemudian dikukus selama 15 menit. Setelah dingin kemudian dimasukkan dalam kantong plastik untuk dikukus kembali selama 10 menit. Setelah media beras jagung dalam plastik kemasan dingin, maka isolat Trichoderma dan B. bassiana dimasukkan ke dalam media dan dilakukan dalam ruang steril (menggunakan enkas dan disemprot dengan alkohol).

Media beras jagung yang telah diberi isolat kemudian diletakkan pada wadah tertutup yang aman dari sinar matahari langsung, serangan semut, atau hewan lain. Jamur Trichoderma dan agensia hayati $B$. bassiana biasanya akan tumbuh pada hari ke lima setelah isolasi. Pupuk hayati Trichoderna akan berwarna hijau dan agen hayati B. bassiana akan berwarna putih. Setelah jamur dan agensia hayati terbentuk penuh di seluruh permukaan media, maka siap untuk diaplikasikan. Apabila terbentuk warna selain itu maka isolasi dikatakan gagal. Kegiatan selanjutnya adalah demonstrasi plot (demplot) pada lahan dengan luasan $240 \mathrm{~m}^{2}$. Lahan dibagi menjadi dua, yaitu lahan teknologi PHT dan lahan dengan teknologi konvensional. Lahan percobaan dilakukan dengan aplikasi $B$. bassiana, Trichoder$m a$ sp., dan penanaman bunga Refugia. Aplikasi $B$. bassiana (dengan konsentrasi $10 \mathrm{~g} / \mathrm{L}$ ) dilakukan setiap tiga hari sekali dengan dikombinasikan pengaplikasian pestisida kimia seminggu sekali dan diawal penanaman tiap lubang tanam diberikan Trichoderma sp. 30 g/lubang serta ditanami Refugia di pinggiran bedengan. Refugia ditanam pada pinggiran lahan cabai dengan jarak $50 \mathrm{~cm}$ dari bedengan dan penanamannya secara 
berseling antara bunga kertas dan bunga kenikir dengan jarak $10 \mathrm{~cm}$. Sementara lahan dengan teknologi konvensional merupakan lahan cabai merah yang biasa dibudidayakan petani, yaitu dengan penyemprotan pestisida kimia setiap tiga hari sekali.

\section{- Evaluasi}

Evaluasi kegiatan pelatihan dan demplot dilaksanakan setelah kegiatan panen selesai. Keberhasilan pelaksanaan program dinilai dengan dua cara, yaitu untuk penilaian pengetahuan tentang PHT dengan kuesioner atau post-test, dan untuk melihat hasil praktik pembuatan pupuk hayati dan perbanyakan agensia hayati dinilai dengan berhasil atau tidak. Evaluasi juga dilakukan dengan materi pembukuan usaha tani cabai merah. Dari kegiatan ini dapat dilihat apakah aplikasi metode Beart dapat memberikan keuntungan secara finansial dalam budi daya cabai merah.

\section{HASIL DAN PEMBAHASAN}

\section{Sosialisasi Program Pelaksanaan Pengabdian kepada Masyarakat}

Program pengabdian kepada masyarakat (PKM) dilaksanakan pada Kelompok Tani Aneka Maju yang merupakan kelompok tani cabai merah di Dusun Gawok, Desa Dukuh Dempok, Kecamatan Wuluhan, Kabupaten Jember. Kegiatan PKM dilaksanakan bulan April-November 2019. Kegiatan diawali dengan sosialisasi yang dilakukan kepada 25 anggota kelompok tani Aneka Maju. Pada kegiatan ini, tim pelaksana kegiatan pengabdian melakukan sosialisasi tentang hama dan penyakit yang menyerang tanaman cabai merah, serta cara pengendaliannya secara bijak (Gambar 1). Sosialisasi dilakukan dengan mengedukasi pada petani tentang

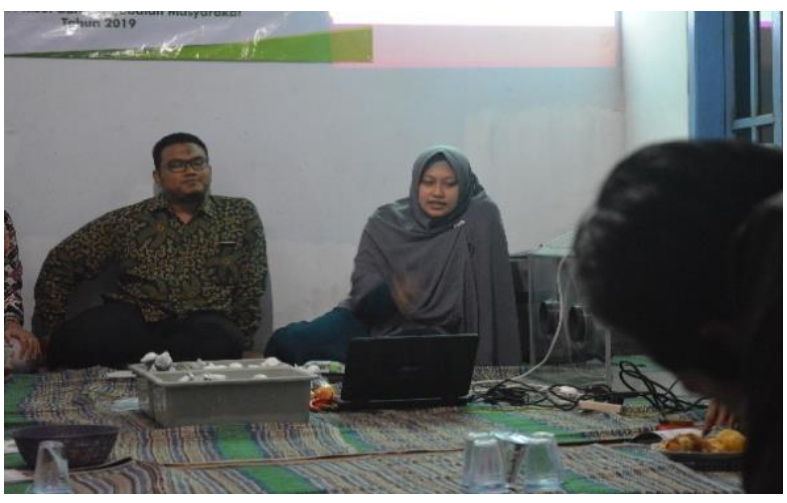

a pengendalian hama terpadu (PHT) dengan metode Beart. Metode Beart merupakan teknologi pengendalian hama terpadu dengan menggunakan agensia hayati $B$. bassiana untuk menekan populasi hama dengan menjadi parasit pada tubuh hama (entomopatogen) (Subagyo \& Hidayat 2014), kemudian penggunaan pupuk hayati Trichoderma sp yang berfungsi menguatkan tanaman agar lebih tahan terhadap serangan penyakit (Duriat et al. 2007), serta penanaman bunga refugia sebagai mikro habitat bagi predator ataupun parasitoid yang dapat menjadi musuh alami bagi hama tanaman cabai. Dengan teknologi PHT metode Beart diharapkan petani dapat menggunakan pestisida kimia dengan bijak, berbudidaya dengan memerhatikan kesehatan lingkungan, dan juga dapat menekan biaya produksi pada usaha tani cabai merah. Kegiatan sosialisasi ini disambut dengan antusias oleh petani, karena sebelumnya petani pernah membeli pupuk hayati Trichoderma di toko pertanian dengan harga yang relatif mahal. Dengan sosialisasi kegiatan ini petani berharap dapat membuat pupuk hayati sendiri sehingga harga dapat lebih murah.

\section{Pelatihan Pembuatan Pupuk hayati Trichoderma dan Agensia Hayati Beveuria bassiana dan Demonstrasi Plot}

Pelatihan pembuatan pupuk hayati dan agensia hayati dihadiri oleh 25 petani anggota kelompok tani Aneka Maju (Gambar 2). Pelatihan dilakukan di rumah ketua kelompok tani. Petani memberikan respons positif terhadap pelatihan yang diberikan, yaitu dengan berpartisipasi melakukan demonstrasi pembuatan pupuk hayati dan agensia hayati. Hasil pelatihan dievaluasi dengan melihat jumlah pupuk hayati dan agensia hayati yang berhasil diisolasikan. Pupuk hayati Trichoderma akan berwarna hijau, sedangkan agensia hayati $B$. bassiana berwarna putih.

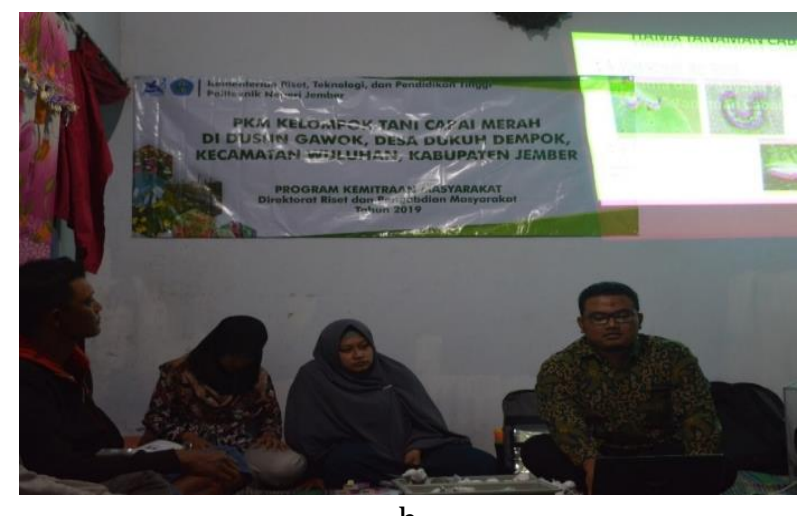

b

Gambar 1 a dan b Kegiatan sosialisasi teknologi pengendalian hama terpadu. 
Apabila hasil isolasi berwarna selain hijau dan putih maka dianggap gagal. Sebagian besar pupuk hayati dan agensia hayati yang dibuat oleh petani dinyatakan berhasil dan siap diaplikasikan.

Kegiatan selanjutnya setelah pelatihan pembuatan pupuk hayati dan agensia hayati adalah demonstrasi plot (demplot) budi daya cabai merah dengan teknologi metode Beart (Gambar 3). Demplot dilakukan pada lahan petani seluas $240 \mathrm{~m}^{2}$ yang dibagi dua, yaitu untuk kontrol (metode konvensional) dan lahan percobaan (dengan teknologi PHT metode Beart). Pestisida sintetis yang diaplikasikan dari golongan insektisida (Demolis $1 \mathrm{~mL} / \mathrm{L}$, Pegasus 1,5-2 mL/L dan Endure $1 \mathrm{~mL} / \mathrm{L}$ ) yang diaplikasikan setiap tiga hari sekali pada lahan konvensional dan satu minggu sekali pada lahan percobaan. Tabel 1 menunjukkan perbandingan perlakuan lahan percobaan dan lahan konvensional. Hal ini berkaitan dengan wilayah demplot yang merupakan red area (area endemik kutu kebul sebagai hama utama cabai), sehingga perlu adanya pengadaptasian teknik pengendalian pada wilayah tersebut.

Sekeliling lahan demplot percobaan ditanami oleh bunga refugia, yaitu bunga kertas dan kenikir (Gambar 4). Kedua jenis bunga ini dipilih karena mempunyai bunga yang selalu mekar dan berwarna mencolok sehingga diminati musuh alami dan banyak dikunjungi serangga dari berbagai jenis kupu-kupu, semut, kumbang, labalaba, dan lebah. Kelebihan lain tanaman ini mudah ditanam (cepat tumbuh), bibit mudah

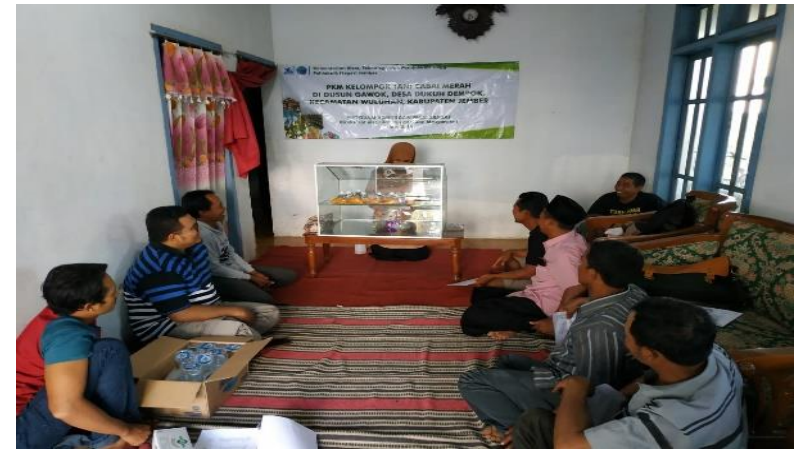

a

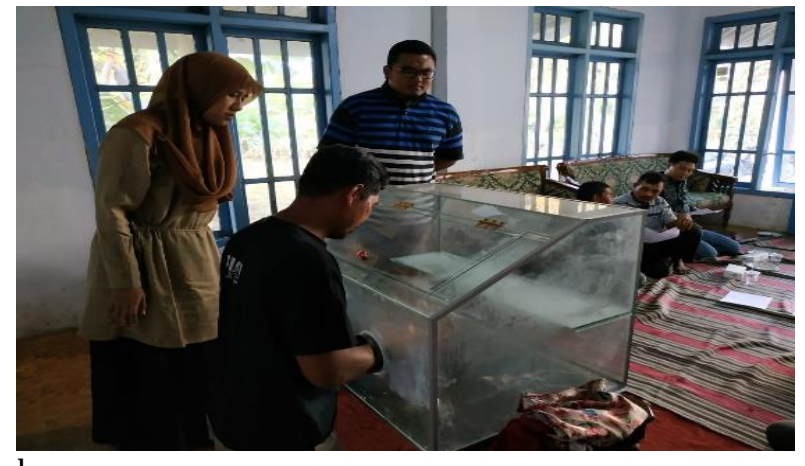

b

Gambar 2 Pelatihan pembuatan pupuk hayati dan agensia hayati

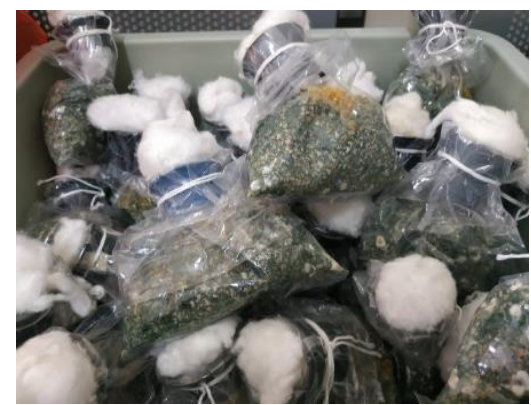

a

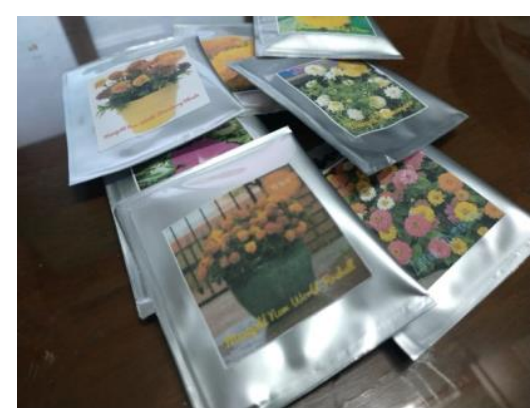

b

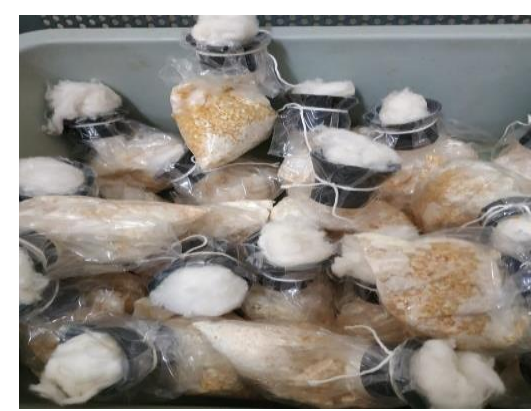

C

Gambar 3 Metode BEART: a) pupuk hayati trichoderma; b) Benih refugia; dan c) Agensia hayati Beveuria bassiana.

Tabel 1 Perbandingan perlakuan lahan percobaan dan lahan konvensional

\begin{tabular}{|c|c|}
\hline Lahan percobaan metode BEART & Lahan konvensional \\
\hline $\begin{array}{l}\text { Aplikasi agensia hayati } B \text {. bassiana dengan konsentrasi } \\
10 \text { g/L setiap } 3 \text { hari sekali }\end{array}$ & Tanpa aplikasi B. bassiana \\
\hline $\begin{array}{l}\text { Pemberian Trichoderma sp dengan dosis } 30 \mathrm{gr} / \mathrm{lubang} \\
\text { tanam }\end{array}$ & Tanpa pemberian Trichoderma sp \\
\hline $\begin{array}{l}\text { Penanaman bunga Refugia (bunga kenikir dan bunga } \\
\text { kertas) yang mengelilingi bedengan }\end{array}$ & Tanpa penanaman bunga Refugia \\
\hline $\begin{array}{l}\text { Aplikasi pestisida kimia (Demolis } 1 \mathrm{~mL} / \mathrm{L} \text {, Pegasus } 1,5- \\
2 \mathrm{~mL} / \mathrm{L} \text {, dan Endure } 1 \mathrm{~mL} / \mathrm{L} \text { ) dengan frekuensi } \\
\text { seminggu satu kali }\end{array}$ & $\begin{array}{l}\text { Aplikasi Pestisida Kimia (Demolis } 1 \mathrm{~mL} / \mathrm{L} \text {, Pegasus } 1,5-2 \\
\mathrm{~mL} / \mathrm{L} \text { dan Endure } 1 \mathrm{~mL} / \mathrm{L} \text { ) dengan frekuensi tiga hari } \\
\text { sekali }\end{array}$ \\
\hline
\end{tabular}




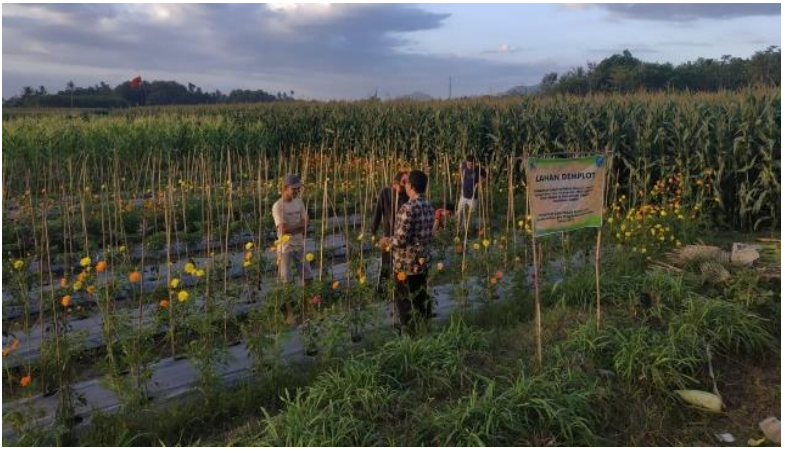

a

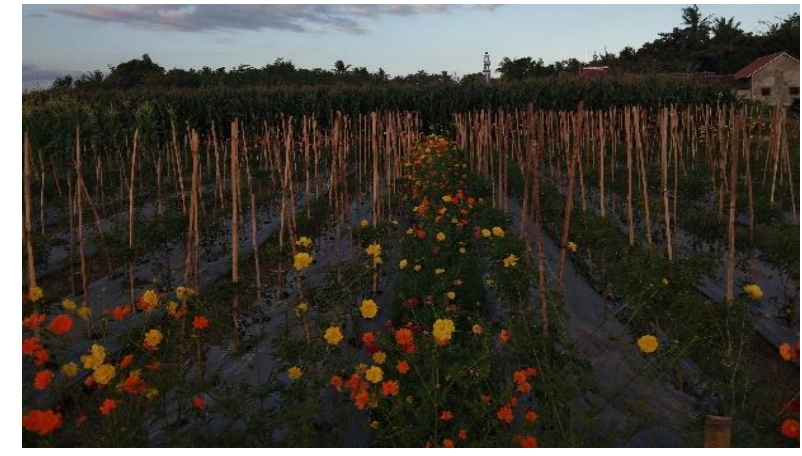

b

Gambar 4 a dan b) Lahan demplot.

diperoleh, regenerasi tanaman tergolong cepat, dan kontinu. Pada lahan demplot percobaan, lubang tanam sebelum penanaman diaplikasikan pupuk Trichoderma dengan dosis 30gr/lubang tanam, dan penyemprotan agensia hayati $B$. bassiana dengan konsentrasi $10 \mathrm{gr} / \mathrm{L}$ air yang dilakukan 3 hari sekali. Sementara untuk lahan kontrol dilakukan budi daya seperti yang biasanya dilakukan petani. Hal yang perlu ditekankan pada teknik pengendalian ini adalah merubah red area (serangan hama tinggi/ledakan hama) menjadi yellow area (serangan medium) atau green area (serangan ringan).

Kegiatan selanjutnya yang dilakukan adalah monitoring lahan demplot dan diskusi. Monitoring dilakukan dengan peninjauan langsung ke lahan demplot. Dalam kegiatan diskusi serta monitoring kegiatan demplot yang dilakukan oleh tim pelaksana pengabdian dengan para petani, dilakukan pengamatan intensitas serangan hama dan penyakit yang dominan menyerang pertanaman cabai merah. Pengamatan dilakukan pada usia pertanaman 1 minggu setelah tanam (MST) hingga 7 MST (Gambar 5). Berdasarkan hasil monitoring pada lahan demplot menunjukkan serangan hama yang dominan adalah Bemisia tabaci, kemudian terdapat juga serangan hama thrips. Berdasarkan pengamatan di lahan diketahui bahwa intensitas serangan hama Bemisia tabaci pada tanaman cabai perlakuan metode Beart terlihat lebih rendah dibanding tanaman cabai pada budi daya konvensional. Hal tersebut terjadi karena semakin berkembangnya tanaman refugia yang berperan sebagai microhabitat predator dan parasitoid, serta aplikasi $B$. bassiana pada lahan perlakuan. Sementara itu berdasarkan pengamatan penyakit tanaman cabai merah yang dominana di lahan adalah penyakit layu fusarium. Intesitas serangan layu fusarium pada lahan percobaan teridentifikasi lebih sedikit dibanding lahan konvensional. Berdasarkan pengamatan dan perhitungan di lahan diketahui bahwa intensitas serangan layu fusarium di lahan percobaan adalah 1,66\% sementara untuk lahan konvensional mencapai 9,58\% (Gambar 6). Hal tersebut dikarenakan pengaruh aplikasi Trichoderma sp pada lahan percobaan. Trichoderma sp merupakan salah satu spesies jamur antagonis di dalam tanah yang sering digunakan dalam pengendalian hayati, baik terhadap patogen tular-tanah seperti layu fusarium. Selain menjadi jamur antagonis untuk jamur lain, Trichoderma sp juga memberikan pengaruh yang positif terhadap perakaran tanaman dan hasil produksi tanaman (Soesanto 2013).

Dalam kegiatan monitoring juga dilakukan pengamatan pada jenis hama yang menyerang pertanaman cabai merah, kemudian juga dilakukan identifikasi beberapa predator dan parasitoid yang dapat menjadi musuh alami bagi hama tanaman cabai. Hasil pengamatan juga menunjukkan bahwa aplikasi metode Beart dapat menjadi upaya pengendalian hama terpadu yang efektif dan efisien. Diskusi dilakukan agar petani semakin memahami dan tertarik untuk menerapkan teknologi metode Beart pada budi daya cabai merah mereka. Monitoring demplot bersama kelompok tani juga dilakukan untuk memastikan bahwa kegiatan budi daya cabai merah telah berjalan sesuai Standart Operating Prosedure (SOP).

\section{Evaluasi Kegiatan}

Evaluasi kegiatan sosialisasi, pelatihan, dan demplot dilaksanakan setelah kegiatan panen selesai. Keberhasilan pelaksanaan program dinilai dengan dua cara, yaitu untuk penilaian pengetahuan tentang teknologi pengendalian hama terpadu (PHT) pada para petani dengan menggunakan kuesioner (post-test) dan melihat keberhasilan pembuatan pupuk hayati dan agensia hayati yang dilakukan oleh para petani, yaitu dengan melihat berapa presentase keber- 


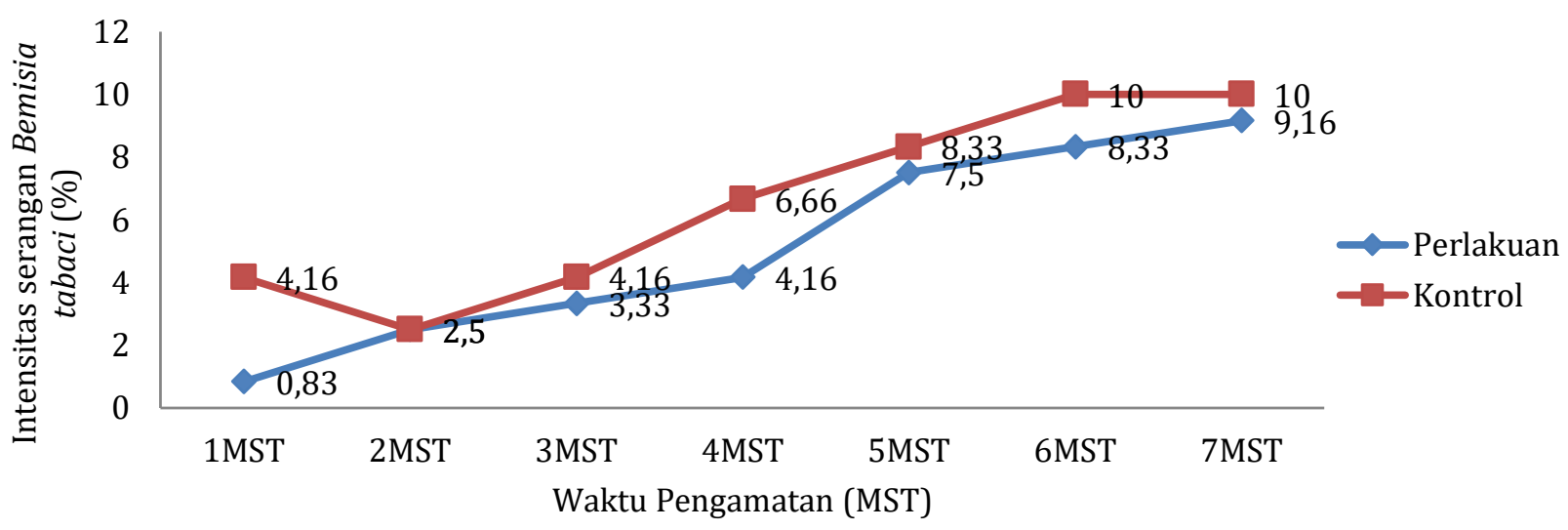

Gambar 5 Grafik intensitas serangan Bemisia tabaci.

hasilan pembuatan pupuk dan perbanyakan agensia hayati yang dilakukan oleh petani.

Efektivitas pelaksanaan kegiatan sosialisasi dan pelatihan diketahui dengan membandingkan nilai pre-test dan post-test (Gambar 7). Kuesioner diberikan sebelum dan sesudah kegiatan sosialisai atau pelatihan. Kuesioner berisi 20 pertanyaan terkait dengan materi pengendalian hama terpadu dalam budi daya cabai merah. Berdasarkan hasil pre-test dan post-test dapat diketahui bahwa terjadi peningkatan pengetahuan petani terkait dengan teknologi PHT pada budi daya cabai merah. Rata-rata nilai pre-test adalah 41,5 dan post-test adalah 87. Sedangkan evaluasi hasil pelatihan pembuatan pupuk hayati dan agensia hayati dilihat dari tingkat keberhasilan petani membuat pupuk hayati dan agensia hayati. Berdasarkan hasil evaluasi dikatakan bahwa tingkat keberhasilan petani dalam membuat pupuk hayati dan agensia hayati mencapai lebih dari $80 \%$.

Evaluasi hasil demplot dilakukan pada hasil panen tanaman cabai. Hasil panen pada lahan konvensional adalah 55,4 kg, sementara panen pada lahan percobaan dengan teknologi metode Beart mencapai 79,1 kg. Pada tanaman lahan konvensional, setiap tanaman cabai merah hanya mampu menghasilkan sampai $413 \mathrm{~g}$, sementara pada tanaman dengan teknologi metode Beart setiap tanaman mencapai 608 g. Evaluasi pelaksanaan demplot juga dilakukan dengan pemaparan hasil usaha tani budi daya cabai merah dengan aplikasi metode Beart dan dibandingkan dengan hasil budi daya cabai merah dengan metode konvensional yang biasa dilakukan oleh petani. Penggunaan metode Beart juga dapat menekan penggunaan pestisida kimia, karena aplikasi pestisida kimia hanya dilakukan sekali dalam satu minggu, berbeda dengan lahan konvensional yang disemprot setiap tiga hari sekali. Berdasarkan pembukuan usaha tani yang

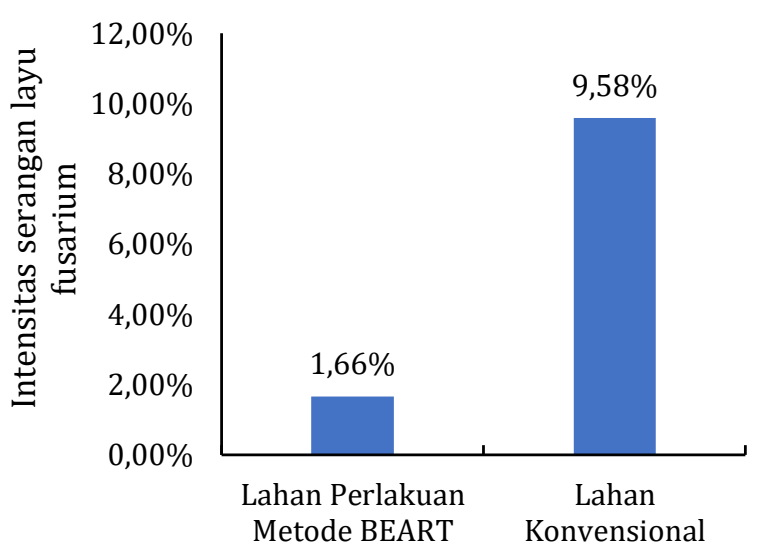

Gambar 6 Grafik intensitas serangan layu fusarium.

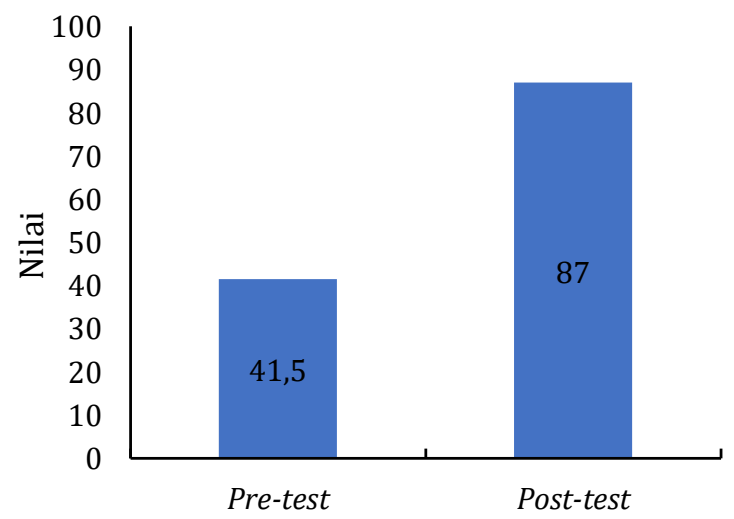

Gambar 7 Hasil pre-test dan post-test pengetahuan petani tentang pengendalian hama terpadu.

dilakukan petani, total biaya untuk pembelian pestisida lahan percobaan menjadi lebih sedikit, yakni mencapai Rp. 70.750 sedangkan biaya pembelian pestisida lahan konvensional mencapai Rp. 141.500 (Tabel 2). Dengan demikian metode Beart dapat menekan penggunaan pestisida hingga 50\%. Berdasarkan analisis usaha tani cabai merah dengan menggunakan metode Beart diperoleh keuntungan (nilai R/C Ratio lebih dari 1) dibanding dengan metode konvensional. 
Tabel 2 Analisis usaha tani cabai merah per luasan $100 \mathrm{~m}^{2}$

\begin{tabular}{llrr}
\hline Keterangan & Satuan & Kontrol & Perlakuan metode BEART \\
\hline Total produksi & $\mathrm{kg}$ & 55,4 & 79,1 \\
Biaya produksi (TC) & $\mathrm{Rp}$ & 1.044 .000 & 1.075 .750 \\
Penerimaan usaha tani (TR) & $\mathrm{Rp}$ & 830.398 & 1.267 .220 \\
Pendapatan usaha tani (I) & $\mathrm{Rp}$ & -213.602 & 191.470 \\
R/C ratio & & 0,80 & 1,18 \\
& & tidak menguntungkan & menguntungkan \\
\hline
\end{tabular}

\section{Kendala yang Dihadapi}

Kendala yang dihadapi dalam kegiatan pengabdian ini adalah cara meyakinkan petani untuk menggunakan teknologi ini secara kontinu. Pengendalian hama tanaman dengan menggunakan pestisida kimia masih menjadi pilihan utama petani, karena selain mudah didapat di toko-toko pertanian, penggunaan pestisida kimia juga memiliki dampak yang cepat. Selain itu, harga cabai merah yang mahal membuat petani akan melakukan upaya apapun untuk menghindari kegagalan panen, termasuk dengan aplikasi pestisida secara berlebihan. Kondisi ini akan menyebabkan teknologi pengendalian hama terpadu (PHT) sulit untuk diterapkan.

\section{Dampak dan Upaya Keberlanjutan Program}

Dampak dan upaya keberlanjutan program pengabdian kepada masyarakat ini adalah penerapan pengendalian hama terpadu dengan metode Beart pada musim tanam di tahun-tahun berikutnya. Pendampingan dan pemantauan akan terus dilakukan oleh tim pelaksana pengabdian dan bekerja sama dengan pemerintah atau penyuluh pertanian lapang di daerah setempat.

\section{SIMPULAN}

Kegiatan pengabdian kepada masyarakat melalui kegiatan Program Kemitraan Masyarakat telah berhasil dilaksanakan dan mampu meningkatkan pengetahuan petani dalam melakukan pengendalian hama terpadu (PHT) pada budi daya cabai merah. Kegiatan pengabdian kepada masyarakat ini juga telah dapat meningkatkan keterampilan petani dalam membuat pupuk hayati Trichoderma, perbanyakan agensia hayati B. bassiana, dan menanam bunga refugia, serta mengaplikasikan teknologi tersebut dalam budi daya cabai merah. Berdasarkan hasil evaluasi dapat diketahui bahwa metode Beart secara efektif dapat menekan populasi OPT pada budi daya cabai merah dan dapat mengurangi penggunaan pestisida kimia hingga 50\%. Diharapkan kegiatan ini dapat terus dilakukan oleh petani dan dengan pendampingan yang intensif dari Politeknik Negeri Jember serta pemerintah terkait agar metode BEART dapat diterapkan petani dalam budi daya cabai merah yang dilakukan.

\section{UCAPAN TERIMA KASIH}

Ucapan terima kasih disampaikan pada Direktorat Penelitian dan Pengabdian Masyarakat, Kementerian Riset teknologi, dan Pendidikan Tinggi atas hibah Program Kemitraan Masyarakat (PKM) tahun pelaksanaan 2019. Ucapan terima kasih juga kami sampaikan pada Pusat Penelitian dan Pengabdian Masyarakat (P3M) Politeknik Negeri Jember atas dukungan teknis, fasilitas, administrasi sehingga kegiatan pengabdian kepada masyarakat ini dapat berlangsung baik dan lancar.

\section{DAFTAR PUSTAKA}

Badan Pusat Statistik. 2015. Jember Dalam Angka 2015. Jember (ID): BPS.

Duriat AS, Gunaeni N, Wulandari AW. 2007. Penyakit Penting Pada Tanaman Cabai dan Pengendaliannya. Bandung (ID): Balai Penelitian Tanaman Sayuran.

Duriat AS. 2015. Pengendalian Hama Penyakit Terpadu pada Agribisnis Cabai. Jakarta (ID): Penebar Swadaya.

Erdiansyah I, Putri SU. 2017. Optimalisasi Fungsi Bunga Refugia sebagai Pengendali Hama Tanaman Padi (Oryza sativa L). dalam: Prosiding Seminar Nasional Hasil Penelitian. Jember (ID): Politeknik Negeri Jember, November 2017.

Hidayat P, Setiawati W, Sulastrini I, Udiarto BK. 2010. Rakitan Teknologi Pengendalian Bemisia tabaci (Gennadius) (Hemiptera:Aleyrodidae) dengan Musuh Alami untuk menekan Insektisida (75\%) dan 
Kehilangan Hasil Cabai (50\%). Hasil-hasil penelitian 2010: Kerja sama Kemitraan Penelitian Pertanian dengan Perguruan Tinggi. Bogor (ID): Institut Pertanian Bogor.

Juanda D, Cahyono B. 2005. Teknik Budi Daya dan Analisis Usaha Tani. Yogyakarta (ID): Kanisius.

Leatema ED, Sari RM. 2012. Pelatihan Pembukuan Usaha tani di Desa Hutumori, Kecamatan Leitimut, Kota Ambon. Jurnal Bakti. 1(1): 17-24.

Narendra AAGA, Phabiola TA, Yuliadi KA. 2017. Hubungan antara Populasi Kutu Kebul (Bemisia tabaci) (Gennadius) (Hemiptera : Aleyrodidae) dengan Insiden Penyakit Kuning pada Tanaman Tomat (Solanum lycopersicum Mill.) di Dusun Marga Tengah, Desa Kerta, Kecamatan Payangan, Bali. Jurnal Agroekoteknologi Tropika 6(3): 339-348.

Rahmawati D. 2016. Kajian Daya Antagonisme Trichoderma spp terhadap Colletotrochum capsici secara In Vitro dan Mekanismenya. [Skripsi]. Malang (ID): Universitas Negeri Malang.
Soesanto L, Mugiastuti E, Rahayuniati RF, Dewi RS. 2014. Uji Kesesuaian Empat Isolat Trichoderma spp. dan Daya Hambat In Vitro Terhadap Beberapa Patogen Tanaman. Jurnal Hama dan Penyakit Tumbuhan Tropika. 13(2): 117-123. https://doi.org/10.23960/j.hptt. 213117-123

Subagyo NVO, Hidayat P. 2014. Neraca kehidupan kutu kebul Bemisia tabaci (Gennadius) (Hemiptera: Aleyrodidae) pada tanaman cabai dan gulma babadotan pada suhu $25^{\circ} \mathrm{C}$ dan $29^{\circ} \mathrm{C}$. Jurnal Entomologi Indonesia. 11(1): 1-8. https://doi.org/10.5994/jei.11.1.11

Sudiono, Yasin N. 2006. Karakteristik Kutu Kebul (Bemisia tabaci) sebagai Vektor Virus Gemini dengan Teknik PCR-RAPD. Jurnal Hama dan Penyakit Tumbuhan Tropika. 6(2): 113-119. https://doi.org/10.23960/j.hptt.26113-119

Untung K. 2015. Pengantar Pengelolaan Hama Terpadu Edisi 2 (Revisi). Yogyakarta (ID): UGM Press. 